\title{
Devonian and Carboniferous research: homage to Professor Edouard Poty
}

\section{Foreword}

\author{
JULIEN DENAYER ${ }^{1} \&$ MARKuS ARETZ ${ }^{2}$
}

${ }^{1}$ Université de Liège, Département de Géologie, Evolution \& Diversity Dynamics - EDDy - Lab, Quartier Agora, B18, Allée du Six-Août, B-4000 Liège, Belgium.

${ }^{2}$ Université de Toulouse (UPS), Géosciences Environnement Toulouse (OMP), Avenue Edouard Belin, 14, F-31400 Toulouse, France.

This special volume in homage to Edouard - Eddy - Poty is dedicated to several scientific topics he developed during his career. Rather than an alphabetic or stratigraphic ordering of the contributions, we chose to present the papers following Eddy's topical chronology, as detailed in the bio- and bibliography of Edouard Poty (compilation by J. Denayer and colleagues).

Hence, the first paper deals not only with Eddy's oldest interest, the Viséan rugose corals from southern Belgium, but also the locality, which he has most intensely studied and sampled during his career, Royseux. J. Denayer and colleagues present in that opening paper the description of this Late Viséan biodiversity palaeo-hotspot in Belgium. It is self-explaining that Eddy is one of the co-authors.

Because taxonomic descriptions are a big and fundamental piece of Eddy's work, V. Ogar presents herein a paper on the systematic of some selected Carboniferous corals from the Ukrainian Donets Basin.

Stratigraphy based on rugose corals is another one of Eddy's oldest research topics. In this volume it is represented by the contribution of S. Rodriguez and colleagues dealing with Serpukhovian coral biostratigraphy in Morocco.

The paper by J.W. Pickett is dedicated to the palaeoecology of the rugose coral genus Symplectophyllum from the Lower Carboniferous of Australia, reflecting one of Eddy's first paper's on palaeoenvironmental pressure on corals.

The following paper on Viséan storm deposits south of the Yangtze Old Land by L. Yao and colleagues pays homage to Eddy's long lasting work in south China.

The work on the lower Carboniferous succession of the Montagne Noire by Eddy in the 1990's and 2000's is here acknowledged by M. Aretz and his paper on the French Kulm facies.

Similarly, H.-G. Herbig provides a review of the Kulm facies of Germany and its correlation with the Belgian Carboniferous. Both papers on the Kulm facies also connect to Eddy's work on the interplay of sedimentary sequences and sea-level fluctuations.

Because Eddy studied (and still studies) the latest Devonian Strunian fauna, the contributions of M. Amler on Strunian rostroconchids, of B. Mottequin and D. Brice on the Strunian brachiopods, and of C. Prestianni and colleagues on the palynology across the Devonian - Carboniferous Boundary perfectly fit in this volume. They are also a reminder for Eddy's long due publication on the Western European corals on this subject!

In the 1990's, Eddy developed an interest in the Late Frasnian Crises and its effect on corals. The paper by D. Weyer provides an overview of the Frasnian coral localities in Germany, whereas the article of M. Coen-Aubert is a revision of the Late Frasnian phillipsastreid corals from Belgium with the introduction of a new genus dedicated to Eddy: Potyphyllum.

Finally, it seems logical to close this volume with Eddy's personal contribution as a synopsis on the Dinantian of Belgium and surrounding areas that occupied him for a long time!

This special issue is not only an homage volume but also an encouragement for Eddy to publish the huge quantity of data he collected and deciphered during is scientific lifetime.

Finally, we take the opportunity here to thank Annick Anceau, chief editor of Geologica Belgica for her priceless help during the editorial process. The reviewers are here gratefully acknowledged for their quick and efficient work: B. Berkowski, C. Brauckmann, J. Fedorowski, O. Kossovaya, M. Legrand-Blain, R. McLean, J.E.A. Marshall, B. Mottequin, A. Munnecke, J.W. Pickett, A. Nützel, S. Rodríguez, G. Sevastopoulo, I.D. Somerville, J. Talent, X.-D. Wang, G.E. Webb, T. Wright and T. Wrzolek. 